\title{
STUNTING RISK ; DESCRIPTION OF MOTHER'S KNOWLEDGE LEVELS ABOUT NUTRITION FOR TOLLS IN BELIMBING PADANG HEALTH CENTER
}

\author{
Aulia Asman', An Aulingga Asman² \\ ${ }^{1}$ D3 Nursing Study Program,Lecturer,Universitas Negeri Padang, Padang \\ ${ }^{2}$ Medical, Doctor, Aisyiyah Hospital Pariaman City, Pariaman
}

Email: aulia.asman@fik.unp.ac.id

\begin{abstract}
Based on the report from the Padang City Health Office, the health service sector reported the nutritional status of toddlers in the city of Padang, among others, the poor nutritional status of 96 toddlers $(3.05 \%)$ and undernutrition status of 385 toddlers $(12.22 \%)$, and normal nutrition 2,622 toddlers $(83,24 \%)$ and over nutrition 47 children under five $(1,49 \%)$. The highest malnutrition status was found in Belimbing Health Center, namely 10 people (13\%) and undernourished as many as 54 people $(69.2 \%)$ of the total number of toddlers as many as 78 people. The purpose of this study was to describe the level of knowledge of mothers about nutrition in children under five at the Belimbing Health Center. This type of research is descriptive which has been carried out at the Belimbing Padang Health Center. The population was all mothers of children under five who visited the Belimbing Padang Health Center totaling 78 people and the sample was taken by a total sampling of 78 people, at the time of the study using a questionnaire by means of a questionnaire. Then the data were analyzed univariately. The results showed $(59.0 \%)$ mothers had low knowledge about nutrition, (51.3\%) mothers had low knowledge about types of nutritious food, (59.0\%) mothers had low knowledge about how to process nutritious food, $(60.3 \%)$ ) mothers have low knowledge about overcoming nutritional problems and $(35.9 \%)$ mothers have low knowledge about signs of adequate nutrition at the Belimbing Padang Health Center. Based on the results of the study, it can be concluded that the level of mother's knowledge about nutrition for toddlers is still low, so it is hoped that health service agencies such as puskesmas, sub-health centers, posyandu, cadres are expected to be able to reactivate health counseling or promotion activities in the community by going directly to residents' homes, especially on mothers who have less knowledge about toddler nutrition.
\end{abstract}

Keywords- Toddler Nutrition, Prevention, Community Health Center

\section{INTRODUCTION}

One of the problems that threaten the quality of human resources in the future is nutrition. The problem of undernutrition is increasingly being recognized as one of the inhibiting factors in the national development process (Almatsier, 2009).

Nutritional problems in Indonesia and in developing countries in general are lack of protein energy (KEP), iron anemia, disorders due to iodine deficiency (IDD), lack of vitamin A (KVA), and obesity, especially in big cities. Malnutrition in children under five is still a problem in Indonesia, even until 2011 there were around 1 million children who experienced malnutrition among the 240 million population of Indonesia. The majority of these cases are in eastern Indonesia, such as NTT and Maluku (Cakrawati \& Mustika, 2012).

WHO census results show that $49 \%$ of the 10.4 million deaths of children under five in developing countries are related to malnutrition, it is recorded that around $50 \%$ of children under five in Asia, 30\% in Africa, 20\% in Latin America suffer from malnutrition. In 2009 there were 5 million children under five (27.5\%) undernourished, 3.5 million children under five (19.2\%) in the level of malnutrition and 1.5 under five with malnutrition (8.3\%). By using the WHO malnutrition prevalence, Indonesia in 2010 was classified as a country with a high nutritional status, because 5,119,935 $(28.47 \%)$ of 17,982,244 children under five in Indonesia (Depkes RI, 2010).

According to the Indonesian Ministry of Health (2011), the Toddler Mortality Rate (AKABA) in 2010 was 44 per 1,000 live births, while the target to be achieved by 
the Millennium Development Goals (MDGs) in 2015 was 32 per 1,000 live births. Nationally, the prevalence of nutritional status of children under five years old based on body weight in 2010 in Indonesia was $17.9 \%$, consisting of $4.9 \%$ poor nutrition and $13 \%$ undernourished, good nutrition $76.2 \%$ and over nutrition.

In West Sumatra, the achievement of the Millennium Development Goals (MDGs) showed quite varied results, such as monitoring health nutritional status in 2012, namely $3.0 \%$ poor nutrition, $16.2 \%$ malnutrition, $83.6 \%$ good nutrition and $2.7 \%$ over nutrition. Meanwhile, the target of the Millennium Development Goals (MDGs) is that less than $15 \%$ of children under five are malnourished and undernourished. So it is estimated that the target can be achieved in West Sumatra (Profile of the West Sumatra Health Service, 2011). Whereas in Padang City in 2012, nutritional status was seen based on body weight by age from 20 health centers in Padang City, there were 48,602 toddlers who came. It is known that the nutritional status of 96 toddlers $(3.05 \%)$ and undernutrition status of 385 toddlers $(12.22 \%)$, and normal nutrition 2,622 toddlers $(83.24 \%)$ and over nutrition 47 toddlers $(1.49 \%)$. Meanwhile, the Public Health Center that has under-fives with malnutrition is Belimbing Public Health Center, which is $3.05 \%$ of the total number of under-fives weighed as many as 3,150 people (DKK Padang, 2011).

Children under five are one of the important posyandu targets because children under five are a large proportion of the composition of the Indonesian population (Depkes RI, 2010). Efforts to overcome malnutrition include increasing family empowerment efforts for household food security, increasing integrated nutrition services and referral systems starting from the Integrated Service Post (Posyandu) level to health centers and hospitals, increasing information communication and education in the food and beverage sector. community nutrition and direct intervention to the target through Supplementary Feeding (PMT), distribution of high doses of vitamin A, iron tablets and syrups and iodized oil capsules (Almatsier, 2009).

Under-five nutrition is influenced by food consumption and the use of nutrients in the body. When the body obtains sufficient nutrients and is used efficiently, optimal nutritional status will be achieved that allows physical growth, brain development, work ability and general health at the highest possible level (Almatsier, 2009).

Malnutrition or malnutrition in toddlers can result in disruption of their physical growth and intelligence. Indirectly, undernutrition can cause their children to die as well as because of certain diseases, malnutrition exacerbates health problems faced by children, namely susceptibility to disease, stunted growth and so on, so it is clear that nutritional problems are a common problem and all families must act. or do something to improve nutrition (Sayogya, 2004).

Research conducted by Yanita (2006) at the Fish Market Health Center in Bengkulu City about the relationship between mother's level of knowledge about nutrition and the nutritional status of children under five, resulted that low knowledge was 0.19 times more likely to be undernourished, compared to high knowledge.

According to Lawrence Green in Notoatmodjo (2010) that there are 3 factors related to behavior, namely: predisposing factors, supporting factors, and driving factors, which include predisposing factors including: knowledge, education, attitudes, experience, work, economic status and motivation. . Meanwhile, the supporting factors include the availability of health resources or facilities, and finally, the driving factors include the role of community leaders, the role of the family and the role of health workers. 
Knowledge can form an attitude and lead to a behavior in everyday life (Notoatmodjo, 2010). Lack of knowledge and misconceptions about food needs and food value are common in every country. Poverty and lack of nutritious food supplies are important factors in the problem of malnutrition. However, there are other reasons that are no less important, namely lack of knowledge about nutrition or the ability to apply information on food produced and available (Ramadhani, 2012).

Mother's knowledge about toddler nutrition is one of the factors that can affect food consumption. If a mother has less knowledge about toddler nutrition, malnutrition can occur in toddlers and the growth and development of toddlers cannot develop optimally. The knowledge possessed by the mother will affect the type and amount of food consumed by her child. One of the causes of nutritional disorders is a lack of nutritional knowledge or willingness to apply information about nutrition in daily life (Ningsih, 2012).

The results of the 2012 Belimbing Health Center annual report, the number of children under five who experienced malnutrition was 10 people (13\%) and undernourished as many as 54 people $(69.2 \%)$ of the total number of toddlers as many as 78 people. Based on the initial survey that the author conducted at the Belimbing Health Center on 10 mothers of children under five through interviews, $6(60 \%)$ mothers said they did not know about nutrition, where 3 people $(50 \%)$ out of 6 people said they did not know about the definition of nutrition, types of nutritious food, 1 person $(16.7 \%)$ mothers did not know about how to process nutritious food and 2 people (33.3\%) mothers did not know about overcoming nutritional problems. Meanwhile, 4 people $(40 \%)$ of mothers said they knew about signs that their children were wellnourished.

Mother's knowledge about nutrition in toddlers is still low, so there is a lot of malnutrition and malnutrition in toddlers. In order for toddlers to avoid malnutrition and malnutrition, it is hoped that mothers of toddlers will increase knowledge about nutrition for toddlers by participating in counseling and Posyandu-Posyandu for toddlers.

\section{RESEARCH METHOD}

This type of research is descriptive which has been carried out at the Belimbing Padang Health Center. The population was all mothers of children under five who visited the Belimbing Padang Health Center totaling 78 people and the sample was taken by a total sampling of 78 people, at the time of the study using a questionnaire by means of a questionnaire. Then the data were analyzed univariately. 


\section{FINDINGS}

\section{Level of Knowledge about the Definition of Nutrition}

The frequency distribution at the level of knowledge about the notion of nutrition can be categorized into 2 categories, namely low and high, which can be seen in the table below:

Table 1.

Frequency Distribution of Mother's Knowledge Level about the Definition of Nutrition to Toddlers at the Belimbing Padang Health Center

\begin{tabular}{|c|c|c|c|}
\hline No. & $\begin{array}{l}\text { Level of Knowledge about the } \\
\text { Definition of Nutrition }\end{array}$ & f & $\%$ \\
\hline $\begin{array}{l}1 . \\
2 .\end{array}$ & $\begin{array}{l}\text { Low } \\
\text { Height }\end{array}$ & $\begin{array}{l}46 \\
32 \\
\end{array}$ & $\begin{array}{l}59,0 \\
41,0\end{array}$ \\
\hline & Total & 78 & 100 \\
\hline
\end{tabular}

Based on table 1. above, it can be seen that more than half $(59.0 \%)$ of mothers have low knowledge about nutrition at Belimbing Padang Health Center.

The results of this study are the same as that of Handayani (2011) who also obtained the same research results regarding the level of knowledge of mothers about the understanding of nutrition in toddlers in the working area of the Alai Health Center, finding that the level of knowledge in the area was very low, namely $(32.3 \%)$ of the respondents. .

Nutrition comes from the Arabic "Al-Ghidza" which means food and its benefits for health. Al-Ghidza can also be interpreted as a food essence that is beneficial for health. Nutritional status is the state of the body as a result of food consumption and use of nutrients. Distinguished between poor, less, good and more nutritional status (Almatsier, 2009).

Based on the results of the study, it can be seen that the level of mother's knowledge about nutrition is low, as can be seen from the results of the questionnaire where $47 \%$ of mothers do not know about the meaning of nutrition.

The researcher's analysis, the low level of mother's knowledge about the meaning of nutrition is caused by the lack of understanding of the mother on nutrition, especially for toddlers, where the lack of mother's desire to find out about nutrition in toddlers both through health workers and the world of information and the low level of mother's education also causes the mother's low knowledge about nutrition. understanding of nutrition in toddlers

\section{Level of Knowledge about Types of Nutritious Food}

The frequency distribution at the level of knowledge about types of nutritious food can be categorized into 2 categories, namely low and high, which can be seen in the table below: 
Table 2.

Frequency Distribution of Mother's Level of Knowledge about Types of Food Nutrition for Toddlers at the Belimbing Padang Health Center

\begin{tabular}{|c|c|c|c|}
\hline No. & $\begin{array}{c}\text { Level of Knowledge about Types of } \\
\text { Nutritious Food }\end{array}$ & f & \% \\
\hline 1. & Low & 40 & 51,3 \\
2. & Height & 38 & 48,7 \\
\hline \multicolumn{2}{|r|}{ Total } & $\mathbf{7 8}$ & $\mathbf{1 0 0}$ \\
\hline
\end{tabular}

Based on table 2. above, it can be seen that more than half $(51.3 \%)$ of mothers have low knowledge about types of nutritious food at the Belimbing Padang Health Center.

The results of this study are the same as that of Handayani (2011) who also obtained the same research results regarding the level of knowledge of mothers about types of nutritious food for toddlers in the working area of the Alai Padang Health Center, finding that the level of knowledge in the area was low, namely $(41.7 \%)$ of the respondents who there is.

Our bodies are formed from substances that come from food, therefore we need food input, namely to obtain substances that the body needs. Good nutrition is an important goal for most people, nutrition is increasingly being seen as an important determining factor in efforts to maintain health and prevent disease. Children under five years of age are a period of formation of the basics of human personality, sensory abilities, thinking skills, language and speaking skills, social behavior and others (Depkes RI, 2001).

Based on the results of the study, the low level of knowledge of mothers about types of nutritious food can be seen from the results of research questionnaires, where $59 \%$ of mothers do not know about nutritious foods for toddlers and $47 \%$ of mothers also do not know about what is contained in food.

The researcher's analysis shows that the low level of knowledge of mothers about types of nutritious food is due to the lack of mothers to ask every health worker in the area where the mother lives about types of nutritious food. In addition, due to the lack of mothers seeking health information about types of nutritious food for toddlers through television and health magazines. In addition, it also affects the age of the mother, such as if the mother is too young, the mother's knowledge about nutrition for toddlers is also lacking.

\section{Knowledge Level of Nutritious Food Processing}

The frequency distribution at the level of knowledge about how to process nutritious food can be categorized into 2 categories, namely low and high, which can be seen in the table below: 
Table 3.

Frequency Distribution of Mother's Knowledge Level on Processing of Nutritious Food for Toddlers at Belimbing Padang Health Center

\begin{tabular}{|c|l|c|c|}
\hline No. & $\begin{array}{c}\text { Level of Knowledge about how to process } \\
\text { nutritious food }\end{array}$ & f & \% \\
\hline 1. & Low & 46 & 59,0 \\
2. & Height & 32 & 41,0 \\
\hline & Total & $\mathbf{7 8}$ & $\mathbf{1 0 0}$ \\
\hline
\end{tabular}

Based on table 3. above, it can be seen that more than half $(59.0 \%)$ of mothers have low knowledge about how to process nutritious food at the Belimbing Padang Health Center.

The results of this study are the same as that of Handayani (2011) who also obtained the same research results regarding the level of knowledge of mothers about how to process nutritious food for toddlers in the working area of the Alai Padang Health Center, finding that the level of knowledge in the area was low, namely $(42.7 \%)$ of the respondents. which exists.

Processing and storage can make nutrients in foodstuffs lost or damaged. Therefore, treat foodstuffs as well as possible, don't just put them in the refrigerator. How to process food affects the quality of its nutrition. The nutritional value of fresh food is better than frozen food, but frozen food is still better than canned food. Frozen vegetables as soon as they are harvested contain more vitamins than fresh vegetables that are transported directly across the region to be marketed.

Based on the results of the study, the low level of mother's knowledge about how to process nutritious food can be seen from the results of the research questionnaire, where $45 \%$ of mothers do not know about how to remove harmful substances or pesticides from the food to be consumed.

Analysis of the researchers, the low level of knowledge of mothers about how to process nutritious food is due to the lack of knowledge of mothers in processing good food and not eliminating the nutritional content in it, where this is due to mothers who do not see television information about good food processing. and correct and not participating in outreach activities on nutritional values, especially for toddlers.

\section{Knowledge Level of Nutrition Problem Management}

The frequency distribution at the level of knowledge about the prevention of nutritional problems can be categorized into 2 categories, namely low and high, which can be seen in the table below: 
Table 4.

Frequency Distribution of Mother's Knowledge Level about Handling Nutritional Problems in Toddlers at Belimbing Padang Health Center

\begin{tabular}{|c|c|c|c|}
\hline No. & $\begin{array}{l}\text { Knowledge Level of Nutrition } \\
\text { Problem Management }\end{array}$ & f & $\%$ \\
\hline $\begin{array}{l}1 . \\
2 .\end{array}$ & $\begin{array}{l}\text { Low } \\
\text { Height }\end{array}$ & $\begin{array}{l}47 \\
31\end{array}$ & $\begin{array}{l}60,3 \\
39,7\end{array}$ \\
\hline & Total & 78 & 100 \\
\hline
\end{tabular}

Based on table 4. above, it can be seen that more than half $(60.3 \%)$ of mothers have low knowledge about overcoming nutritional problems at the Belimbing Padang Health Center.

The results of this study are almost the same as the research conducted by Susanti (2011) on the description of the level of knowledge of mothers about nutrition in toddlers in the Air Cold Padang Health Center Work Area, where 57.9\% of mothers have low knowledge about handling nutritional problems.

The solution is to balance energy input and output through reducing food and adding physical exercise or sports and avoiding life pressure or stress (Almatsier, 2009). Overcoming the problem of malnutrition, needs to be carried out in an integrated manner between departments and professional groups through efforts to increase food supply, diversify food production and consumption, increase socio-economic status, public health education, and improve agricultural product technology and food technology. This aims to obtain an improvement in food consumption patterns, a diverse and balanced society in nutritional quality (Almatsier, 2009).

Based on the results of the research that has been obtained, the low level of mother's knowledge about overcoming nutritional problems can be seen from the results of the research questionnaire, where $64 \%$ of mothers do not know about maintaining good nutrition in toddlers.

Researcher's analysis, the low level of knowledge of mothers about overcoming nutritional problems in toddlers because overcoming nutritional problems, especially problems of undernutrition and malnutrition requires sufficient understanding for mothers in preventing undernourished and malnourished children under five. Mothers who have low knowledge will find it difficult to overcome nutritional problems for toddlers because of the lack of information obtained and also the lack of mother's education about nutritional problems in toddlers, this will lead to low knowledge of mothers about how to overcome nutritional problems in toddlers.

\section{Level of Knowledge about Signs of Adequately Nutrient Children}

The frequency distribution at the level of knowledge about signs of children being adequately nourished can be categorized into 2 categories, namely low and high, which can be seen in the table below: 
Table 4.

Frequency Distribution of Mother's Knowledge Level about Signs of Enough Children with Nutrition in Toddlers at Belimbing Padang Health Center

\begin{tabular}{|l|l|c|c|}
\hline No. & Level of Knowledge about Signs of Adequately \\
Nutrient Children & f & \% \\
\hline 1. & Low & 28 & 35,9 \\
2. & Height & 50 & 64,1 \\
\hline & Total & $\mathbf{7 8}$ & $\mathbf{1 0 0}$ \\
\hline
\end{tabular}

Based on table 5. above, it can be seen that less than half (35.9\%) of mothers have low knowledge about signs of adequate nutrition at the Belimbing Padang Health Center.

The results of this study are different from the research conducted by Susanti (2011) on the description of the level of knowledge of mothers about nutrition in toddlers in the Air Cold Padang Health Center Work Area, where 51.3\% of mothers have low knowledge about signs of adequate nutrition.

According to the Ministry of Health of the Republic of Indonesia (2007) in Yanni's research (2008), signs of adequate nutrition under five are growing well, which can be seen from the increase in weight and height on a regular basis, the level of development according to the age level, looks active, agile and happy, eyes clean and shining, good appetite, lips and tongue look fresh, skin and hair look clean and not dry, easy to adapt to the environment and breath odorless.

Based on the results of the study, the low level of mother's knowledge about signs of a child being adequately nourished can be seen from the results of the research questionnaire, where $58 \%$ of mothers do not know about how to know the nutritional status of toddlers.

The researcher's analysis shows that there are still mothers who have low knowledge about signs of adequately nourished children because mothers do not get health information from local health workers about signs that their toddlers are adequately nourished. Mothers only know that if a toddler is not sick, it means that the toddler is healthy, and it also affects the mother's level of work. With the low level of mother's work, the mother's knowledge will also be low.

\section{REFERENCE}

Arikunto,(2010), Metode penelitian,Jakarta

Arikunto. (2006). Prosedur Penelitian.Rineka Cipta.Jakarta

Asman, A., Fatimah S. (2020).Implementation of Universal Awareness in Management of Hospital Environment as A Business for Prevention of Nosocomial Infections in Pariaman Regional General Hospital Science and Environmental Journals for Postgraduate Vol. 2 No. 2 (pp. 14-23) June 2020p_ISSN 2655-5085e_ISSN

2655-5239. http://senjop.ppj.unp.ac.id/index.php/senjop

Asman, A., Asman, A., Alfina, R. (2020)., The Model of Trauma Healing Policy for 
The Tsunami Disaster Mitigation in Padang, Indonesia. Sumatra Journal of Disaster, Geography and Geography Education, December, 2020, Vol. 4, No. 2, pp. 212-219 Disaster, Geography, Geography ducation,http://sjdgge.ppj.unp.ac.id/index.php/Sjdgge ISSN : 2580 - 4030 ( Print ) 2580 - 1775 ( Online), Indonesia

Asman, A., Barlian, E., Fatimah, S., Dewata, I., Asman, A. (2020)., Model of Trauma Healing Policy For Communities in the COVID-19 Pandemic Period in Padang City- Indonesia. Jour of Adv Research in Dynamical \& Control Systems (JARDCS), Vol. 12, 07-Special Issue, 2020

Asman, A., Asman, AK., Dewi, (2020)., (2021) Community Nursing Strategies for Tourism

Health Families during COVID-19 Pandemic, Vol. 5 No. 3 December 2021, pages: 224-231 e-ISSN: 2550-696X, p- ISSN: 2550-6978.

https://sciencescholar.us/journal/index.php/ijhs/article/view/1449

Almatsier, 2009. Prinsip Dasar Ilmu Gizi. Jakarta: Gramedia Pustaka Arisman, 2002. Buku Ajar Ilmu Gizi; Gizi Dalam Daur Kehidupan. Jakarta; EGC Ayusita, Laksmi, 2012. Tips Sehat \& Cerdas Seputar Kehamilan \& Persalinan. Yogyakarta: Araska

Budiarto, Eko, 2002. Biostatika Untuk Kedokteran dan Kesehatan Masyarakat. Jakarta: EGC

Budiman \& Riyanto, 2013. Kapita Selekta Kuesioner Pengetahuan dan Sikap Dalam Penelitian Kesehatan. Jakarta: Salemba Medika

Cakrawati dan Mustika, 2012. Bahan Pangan, Gizi dan Kesehatan. Bandung: Alfabeta Depkes RI, 2001. Direktorat Gizi Masyarakat. Jakarta : Depkes RI

Handayani, 2011. Gambaran Tingkat Pengetahuan Ibu Tentang Jenis Makanan Bergizi pada Balita di Wilayah Kerja Puskesmas Alai Padang

Khomsan, A, 2003. Pangan dan Gizi untuk Kesehatan. Jakarta : Kompas

Ningsih, Putri, 2012. Hubungan Pengetahuan Ibu Tentang Gizi buruk dengan Status Gizi Balita di Posyandu Kelurahan Balai Gadang Wilayah Kerja Puskesmas Air Dingin.

Notoatmodjo, Soekidjo, 2003. Pendidikan dan Perilaku Kesehatan. Jakarta: Rineka Cipta 2005. Metodologi Penelitian Kesehatan. Jakarta: Rineka Cipta , 2010. Ilmu Perilaku Kesehatan. Jakarta: Rineka Cipta 2010. Metodologi Penelitian Kesehatan. Jakarta: Rineka Cipta 2012. Promosi Kesehatan dan Perilaku Kesehatan. Jakarta: Rineka Cipta

Ramadhani, 2012. Pengetahuan dalam Pemenuhan Gizi Balita dan Status Gizi Balita di Kelurahan Helvetia Tengah Kecamatan Medan Helvetia. Skripsi FK-USU

Santoso \& Ranti, 2001. Kesehatan dan Gizi. Jakarta: Asdi Mahasatya

Sayogya, 2004. Menuju Gizi Baik yang Merata di Pedesaan dan di Kota. Universitas Gajah Mada. Bogor

Supariasa I Dewa Nyoman, dkk, 2012. Penelitian Status Gizi. Jakarta : EKG

Susanti, 2011. Gambaran Tingkat Pengetahuan Ibu Tentang Gizi pada Balita di Wilayah Kerja Puskesmas Air Dingin Padang.

Wawan, \& Dewi, 2010. Teori \& Pengukuran Pengetahuan Sikap dan Perilaku Manusia. Yogyakarta: Nuha Medika 
Jurnal Cahaya Mandalika, Vol. 2, No. 3, November 2021 ,e- ISSN: 2721-4796

Available online at: http://ojs.cahayamandalika.com/index.php/JCM

Copyright @ $\odot 2021$ Publisher: Institut Penelitian \& Pengembangan Mandalika Indonesia

Yanni, 2008. Efektivitas Program Peningkatan Gizi Bayi dan Balita dalam Pelayanan Kesehatan Masyarakat di Puskesmas Padang Bulan. Universitas Sumatera Utara.

Yanita, 2006. Hubungan Tingkat Pengetahuan Ibu tentang Gizi dengan Status Gizi Anak Balita di Puskesmas Pasar Ikan Kota Bengkulu 